\title{
Responsive Student Dormitory Design with Hybrid Ventilation Strategy in Education Region of Malang City
}

\author{
Guruh Pratama Zulkarnaen \\ Architecture Design, Department of Architecture, \\ Sepuluh Nopember Institute of Technology. \\ Jl. Simpang Raya Candi VI A-14, Malang, 65144, Indonesia
}

\author{
Sri Nastiti Nugrahani Ekasiwi \\ Senior Lecturer of Architectural Science and Technology, \\ Department of Architecture, \\ Sepuluh Nopember Institute of Technology, \\ Surabaya, Indonesia
}

\author{
Ima Defiana \\ Senior Lecturer of Architectural Science and Technology, Department of Architecture, \\ Sepuluh Nopember Institute of Technology, \\ Surabaya, Indonesia
}

\begin{abstract}
This design thesis is related to the concept of responsive Student Dormitory design to meet the main function aspects of dormitory with good thermal comfort and good air quality in buildings in addressing the needs of dormitory facilities and highland micro climate change in the education area of Malang City. The design refers to the principles of the Bioclimatic Architecture using a hybrid ventilation strategy of $30-35 \%$ of the facade area to maximize ventilation performance on users and buildings as well as wider space size $<6 \mathrm{~m}$ and height $>3 \mathrm{~m}$ will enable a high percentage of success.
\end{abstract}

\section{Keywords: Dormitory, Ventilation, Micro Climate.}

\section{INTRODUCTION}

\section{A. Background}

Currently, global warming and energy crisis become a matter of debate by some experts, especially researchers and experts in the field of environment and of course [1]. One of the problems of global warming that can be seen from climate change in temperature, weather and others. In Indonesia alone the problem has occurred in one city in Indonesia, namely Malang with the reality of Malang city climate which in the last time it felt increasingly hot increases $3{ }^{\circ} \mathrm{C}$ to reach $31^{\circ} \mathrm{C}$ in 2012 [2].

In the Development Planning Program of Malang City Government is seen Sustainable Development which will be applied to each building designed in the future. A sustainable development approach, building with a view to energy savings as well as a considerable reduction in temperature in buildings. An innovative and exciting solution is the Bioclimatic Design system with the application of a microclimate climate design strategy for building design [1].

To overcome this problem, we need some new innovations in the field of architecture to design buildings that can respond to microclimate one of them is to apply the approach of Architecture Bioklimatik which emphasizes the design of the building by utilizing the maximum condition of nature and microclimate environment in tropical climate which will be very profitable for minimize negative impacts on the environment.

designing a dormitory enables environmental sustainability in the design to be thought of as a result [3]. The level matrix of significance of steps for sustainability such as: 1) Noise with moderate impact, 2) water quality with moderate impact, 3) air quality with low impact, 4) environment with moderate impact. Focusing on air quality through the use of ventilation that the design of ventilation at the dorm should combine the design synchronization with the concept of ventilation design to meet all aspects for the residents, buildings and environments that accommodate student activities one of which is a good residence for residents, comfortable learning activities and quiet as well as intimate and intimate socialization activities among the inhabitants but remain context-responsive to the environmental microclimate.

[1] Related Ecological and climate aspects that buildings with the application of ventilation systems can provide benefits to ecologists, the environment and users. [4] Ventilation as a shroud medium into a building facade has a function where interaction first occurs between the interior of the building and the exterior of the building.

Hybrid Ventilation Application will be suitable to be free from student dormitory function which require thermal comfort and good air quality for users in the move. Hybrid Ventilation combines ventilation on the facade naturally and mechanically. All components of hybrid vents can be utilized by optimizing the use of natural driving forces ie winds adapted to the solution to be completed in the building. Hybrids are intended to function as needed and function as natural or mechanical ventilation if necessary for the quality of occupant dwelling and productivity of dorm user activity by utilizing the potential of wind flow.

\section{B. Location}

The location of the tread is located on the road of Villa Bukit Tidar Merjosari Subdistrict, Lowokwaru Sub-district, 
Malang City, North Malang. Selection of sites in Merjosari Subdistrict of Lowokwaru District is intended to find potential land for student dormitory development with hybrid vent hybrid strategy approach based on specific design criteria, which are as follows:

a. Based on the direction of development plan of education facility of Malang city which is listed on RAPERDA and RTRW Malang

b.The availability of large areas that do not limit the extent of the building footprint and free from obstacles that block the flow of wind

c.Close to Dormitory Planning support facilities that is close to educational establishments and other supporting facilities

d.Related to the function of the building (land use)

e.Potential as design land. this is reinforced by the notification of the construction of educational facilities in the area around the site

f. the implementation of a new concept of development in the city of Malang is the concept of Sustainable Building

g.Location Site on the plateau $(450 \mathrm{dpl})$ and with supporting climatic conditions and minimal building density that can maximize wind flow.

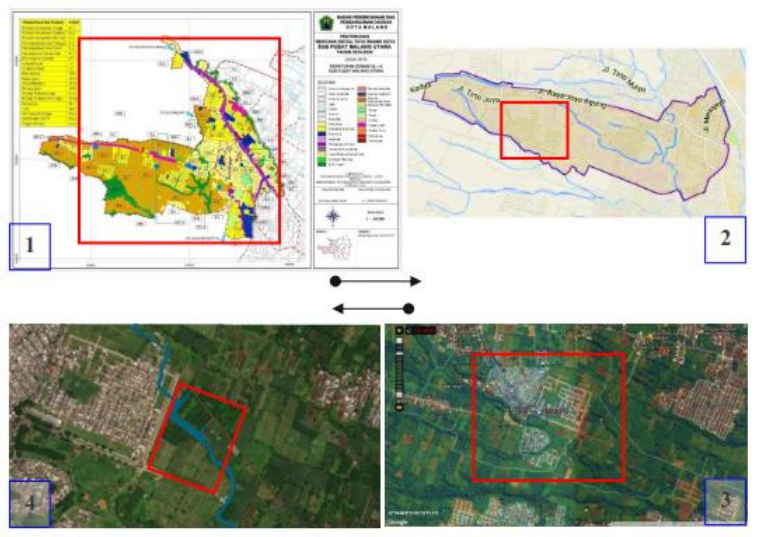

Fig.1 The Map of Study Area

\section{LITERATURE REVIEW}

\section{A. Architectural of Student Dormitory}

Student dormitory is an environment as a residence in the form of buildings with rooms that can be occupied by several residents in each room for a longer period by students who are taking a study or activity activities. In further developments it is possible to have supporting facilities such as libraries, book procurement, canteen, sports and other facilities required by students [5].

Aspects of dorm study include:

- Type and Type of Dormitory

type of student hut (dormitory) is divided into 4 from small huts to large huts. management system, dormitories are divided into 3 types [6]: Self contained, commercial and subsidized,

- Residential Room Size and Type

Size and type of room is 1 room occupied 1 person (single room), 1 room occupied 2-3 person (double / triple room) and 1 room occupied 4 person (fourstudent room).

\section{- Dorm Room Requirement}

space to support student learning activities, and accommodate all activities and basic needs of students will be a place to live and place socialize among fellow dormitories.

- Room Condition of Residential Dormitory

Associated with aspects of ventilation, humidity, lighting and occupant density.

- Aspects of Residential Dormitory Activity

[7] activity in student dorm is sleep (shelter), study (education) and gather

\section{B. Bioclimatic Architecture Approach}

Bioclimatic approach is design by using climate analysis around each building. Understanding the climate according to Big Indonesian Dictionary is the condition of air (temperature, humidity, vulnerability, rain, and sunlight) in a region for a long period of time in an area.

Natural elements that determine the climate are divided into 3 :

\section{Radiation of the sun}

The sun is a natural energy source. Influence caused by the movement of the sun, among others, the effects of heat, solar radiation, and glare.

2. Wind

The influence of the wind and the sun's path to the building can be utilized through open-aired buildings with sufficient distance between buildings to keep air motion secure. The orientation of the building can be placed on the path of the sun and the wind in buildings that run from east to west or that are perpendicular to the wind.

3. Humidity

Humidity is a precautionary measure of buildings that affect the sustainability, use and management of buildings.

Climate in the design of buildings with a bioclimatic approach is an important aspect of climate-responsive building design. So from the elements that will come out on the design can be the main point of focus on the function of the building itself. Climate effect leads to comfort which is divided into 2, among others:

1. Climate to buildings

Buildings are made openly with sufficient distance between building masses for safe air movement. The orientation of the building should be placed between the path of the sun. A rectangular building to maximize cross ventilation. Leaving at least $30 \%$ of the building's land is open for reforestation

2. Climate to humans

Like buildings, climate can also affect humans. Climate can certainly lead to impaired thermal equilibrium in the human body.

\section{Principle of Bioclimatic Facades}

Bioclimatic architecture focuses on the comfort of the inhabitants by the close relationship between the building (the applied system) and the Climate ( site and microclimate of the region) [4]. Based on that, the existence of 
Bioklimatik which focused on Bioclimatic Facade become a system applied to building and micro climate from tread which become comfort factor for its occupant.

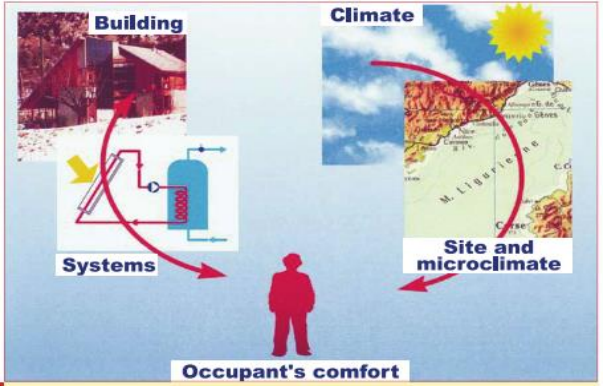

Fig.2 Occupant Comfort Relationship

Bioklimatik facade into a media or architectural elements that need to be considered, especially the orientation that resulted in the application of the facade system in the building. Because it takes into account bioclimatic also microclimate around the site is also not separated to be noticed. The orientation of the facade on each eye has its own advantages and disadvantages.

[4] Current architectural solutions or architectural strategies for facade applications in bioclimatic buildings are transparent gloss facades or Highly glazed facades.
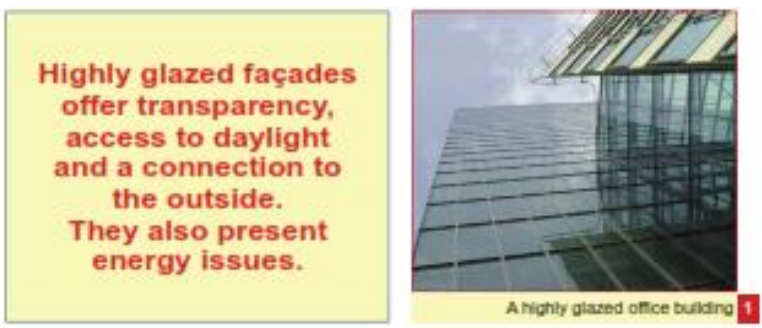

Fig.3 Application of Highly Glazed Facades on Buildings

The architectural elements of the facade can not be separated from its role other than as a display as well as an intermediary flowing air or air ventilation from outdoor to indoor buildings. Ventilation on the Bioklimatik facade will be more optimally functioning by applying a second facade skin type or double-skin Facade.

Application of ventilation as a second skin facade in bioclimatic buildings can be divided such as:

a. Naturally ventilated double skin façades

b. Mechanically ventilated double skin façades

c. Hybrid ventilated double skin façades

d. Airflow window

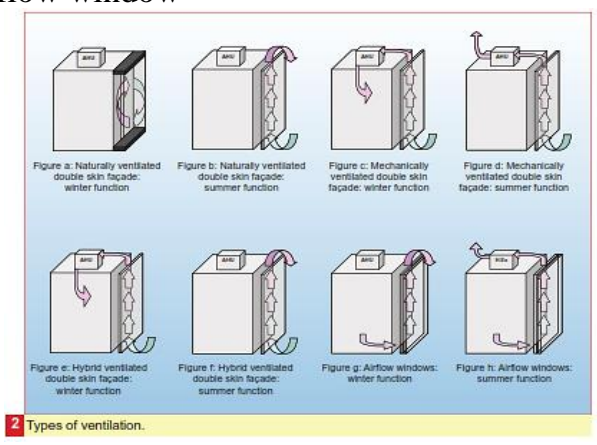

The right kind of ventilation depends on a number of factors such as building location, orientation, climate type, local environment, occupation density, etc.

\section{Context of Plateau}

The plateau is a plain located at an altitude above $200 \mathrm{~m}$ above sea level. High altitudes have air humidity as well as high soil moisture, temperate temperatures tend to be cool (This highland can have a cool climate because it is influenced by its height, because the higher a place will have a cooler air the higher also, or it can be said that the air will get colder.)

But the highlands have relatively low rainfall, large daily and annual temperature amplitude; Dry air (Although it has a mild climate of altitude, but the highlands actually have drier air and drier than other air on the plains that are not high), Lengas (air humidity) relative is very low.
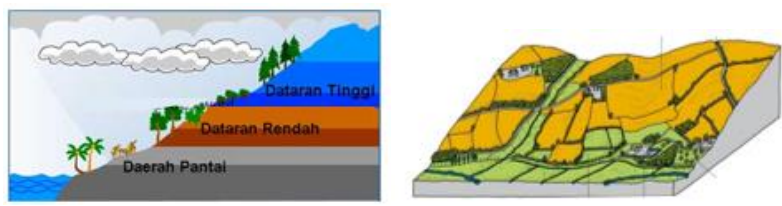

Fig.5 Location and Topography of Plateau

The design of a building is strongly influenced by the location of the building. One of them Student Dormitory Building in Malang City with approach of Architecture of Bioklimatik, if studied in depth environment become main key in designing comfortable dormitory. Aspects - aspects that can be used as a reference to achieve the desired goals can include physical conditions, policy authority, and the condition of urban elements.

As its designation as a Student Dormitory building, the northern Malang area of the western part of Lowokwaru subdistrict is a vast plateau into an educational area. These site locations include areas that have good soil conditions with a combination of flat and contoured.

\section{E. Hybrid Ventilation}

Hybrid Ventilation is selected under conditions that allow on building sites to provide residents comfort. The use of these architectural elements is quite new and there are still many challenges to be faced and solved. Ventilation as an architectural form of building becomes one of the elements that currently can be chosen by the architects. To be developed.

[8] Today the development of sustainable buildings is a way to interact or bring the outdoor environment into the indoor environment. Sustainable technology such as ventilation that is utilized depends on the microclimate outside the building, building function, building location and building design. The choice of technology can not be separated from meeting the demands of thermal comfort (temperature quality) and air quality.

Hybrid Ventilation System serves as an air duct where air can flow well from and into the building by combining between natural and mechanical. This has made it possible to meet relatively strict air quality requirements indoors for most of the time [9]. A responsive Hybrid Ventilation

Fig.4 Application of Bioclimatic Facade Ventilation 
system can be described as providing the comfort of the internal environment using different features of both natural and mechanical ventilation at different times of day or year. This is a ventilation system in which mechanical and natural forces are combined in a two-mode system.

The principles and strategies of hybrid ventilation and its concept vary widely at the level of building integration and industrialization. Integration of buildings and ventilation systems is more important when natural ventilation plays a dominant role for indoor air quality control.

There are three examples that can be illustrated from the Hybrid Ventilation principle:

1. Natural and Mechanical Ventilation

This principle is based on two autonomous systems where the control Strategy either switches between two systems, or uses one system for multiple Tasks and other systems for other tasks.

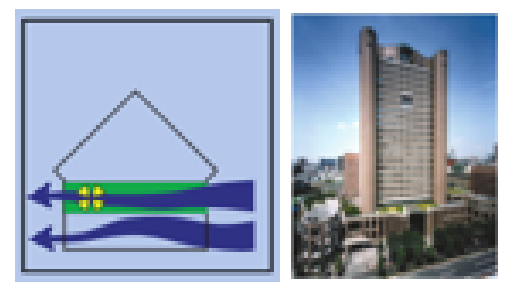

Fig.6 Principle "Natural and Menchanial Ventilation" (Case Study : "Liberty Tower of Meiji University" Tokyo, jepang )

2. Fan-assisted Natural Ventilation

This principle is based on a natural ventilation system combined with the supply of a fan extractor.

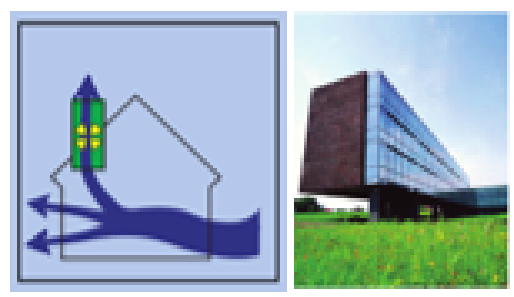

Fig.7 Principle "Fan-assisted Natural Ventilation" (Case Study : "B\&O Headquarters" Struer, Denmark )

3. Stack- and Wind-assissted Mechanical Ventilation This principle is based on a mechanical ventilation system that makes optimal use of natural driving forces.

Fig.10 Site Conditions and Site Area

\section{METHODOLOGY}

The design of this student dormitory has a typology of design problem that is ill-defined problems or ill-structured problems because it wants to explore exploration of clear design solution so as to choose a suitable design process model and can help solve design problem. The design process of designing the Student Dormitory is through several stages similar to the Design Process of Archer's prescriptive model [10]. Here is the schematic of Prescriptive Model design process by Archer:

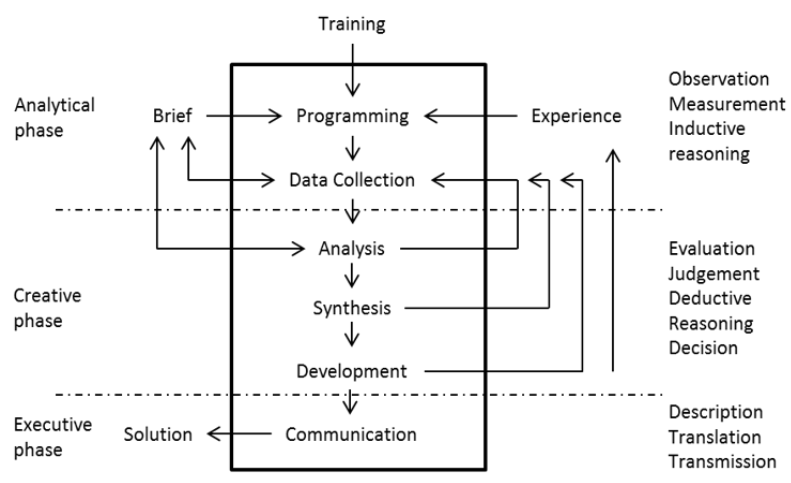

Fig.9 Process Design Model Archer

Description of stages of the design process with Archer model is divided into 3 main phases:

1. Analytical Phase - Research Phase

2. Creative Phase - Design Stage

3. Executive Phase - Design Phase

\section{RESULT AND DISCUSSION}

The explanation of site-related conditions is based on an analysis of the previous siting site which contains the basis for determining the location, size of area and microclimate site conditions. In this site analysis, it will look at the design aspects of the dormitory functionality associated with the matrix of specific design criteria relations for the site context with design elements and site-specific design specific criteria.

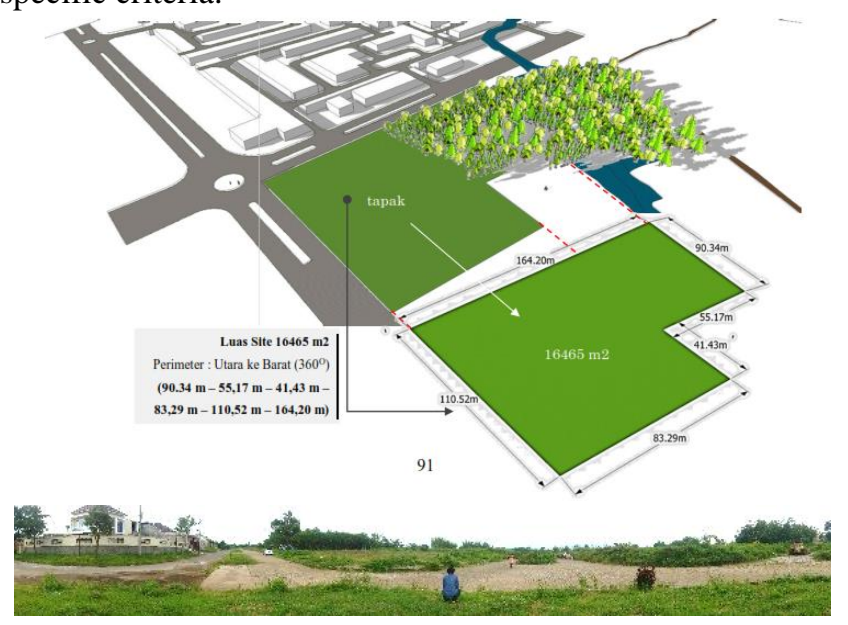

Fig.8 Principle "Stack- and Wind-assissted Mechanical Ventilation" (Case Study : "Media School" Norway )

Based on Specific Design Criteria and the relationship matrix of the site context. This provides the basis for site analysis which will then be linked to the matrix of design element relationships and thematic quality: 


\begin{tabular}{|c|c|c|}
\hline & & $\begin{array}{c}\text { DESIGN } \\
\text { ELEMENTS }\end{array}$ \\
\hline & & SITE \\
\hline \multirow{10}{*}{$\begin{array}{l}\bar{z} \\
\bar{y} \\
0 \\
0 \\
0 \\
0 \\
0\end{array}$} & Bioclimatic Aspects & \multirow{10}{*}{$\begin{array}{c}\text { STRONG } \\
\text { RELATIONSHIPS }\end{array}$} \\
\hline & Bioclimatic Design & \\
\hline & Climate Defining Elements & \\
\hline & Comfort-related climate effects & \\
\hline & Occupant's Comfort & \\
\hline & Facade Orientation & \\
\hline & Ventilation of Bioclimatic Facades & \\
\hline & Hybrid Ventilation & \\
\hline & $\begin{array}{l}\text { Relationship of the floor plan, with } \\
\text { elevation and section }\end{array}$ & \\
\hline & Overall Unit & \\
\hline
\end{tabular}

From the relation matrix of the context component of the site and the design elements, it is seen that for the closely related relationships of the site ie Location, Topography, Climatology, Vegetation, View, Surrounding Buildings, Circulation. This will serve as the basis of strength in analyzing the site which is also related to the criteria and matrix of the relations of design and thematic quality aspects.

The next stage proposes, sorting and infer from the component of the Site Analysis which will be used as a reference to be developed as a result of synthesis of design aspects combined with programmatic analysis and mass building analysis. This is a component table of the tread design elements to be deduced for synthesis.

\begin{tabular}{|c|c|c|}
\hline \multirow{4}{*}{$\begin{array}{c}\text { COPONENT } \\
\text { Design elements of } \\
\text { site }\end{array}$} & Location & $\mathrm{V}$ \\
\cline { 2 - 3 } & Topography & $\mathrm{V}$ \\
\cline { 2 - 3 } & hidrology & $\mathrm{x}$ \\
\cline { 2 - 3 } & climatology & $\mathrm{v}$ \\
\cline { 2 - 3 } & vegetation & $\mathrm{v}$ \\
\cline { 2 - 3 } & Zone, land use & $\mathrm{x}$ \\
\cline { 2 - 3 } & View & $\mathrm{V}$ \\
\cline { 2 - 3 } & Building Around & $\mathrm{V}$ \\
\cline { 2 - 3 } & Linkage & $\mathrm{x}$ \\
\cline { 2 - 3 } & Circulation & $\mathrm{V}$ \\
\cline { 2 - 3 } & Utility & $\mathrm{x}$ \\
\hline
\end{tabular}

Synthesis Analysis Site : Climatology (Sunlight)

- The potential of sunlight can be utilized to reduce the humid air quality later on so it is adjusted to the main

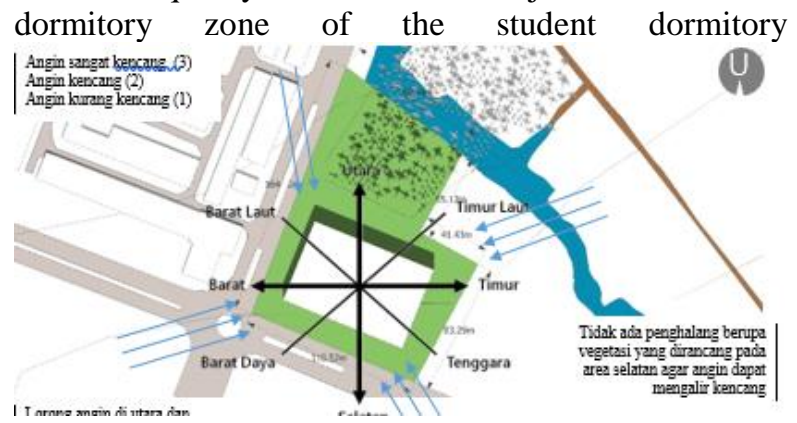

Fig.12 Climatological Analysis of The Site (Wind Flow)
- Direct sunlight radiation is minimized about inner space for convenient activity with the application of sun shading on a second facade integrated with a hybrid ventilation strategy

- Orientation that extends east and west direction will be maximized by tread orientation with oblique sun path to radius that exceeds 5 degrees minimum biocliatics of ken yeang and reduces the impact of shadows occurring in the surrounding environment

- climate integrity is preferred for comfort fulfillment so as to maximize reflected rays from the sun to reduce the reduction of the sun in space.

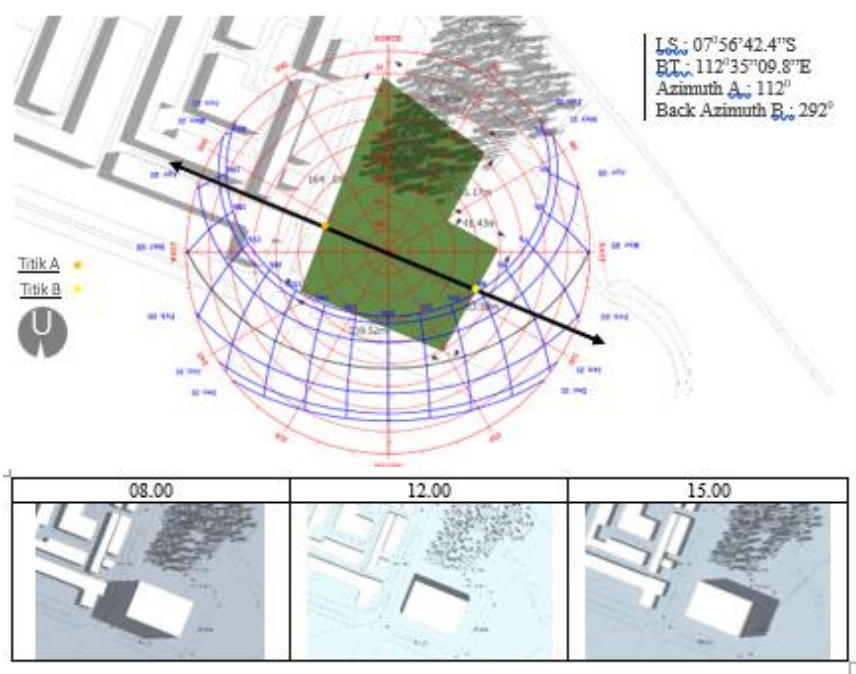

Fig.11 Climatological Analysis of The Site (sunlight)

Synthesis Analysis Site : Climatology (Windflow)

- Climate in the form of wind flow treads already meet data for the application of hybrid ventilation for the comfort of activity, thermal comfort and air quality.

- Avoid large and wide massive barriers in the maximum area of winds, especially east and west, trees can be applied apart from being green as well as steering.

- Site criteria aligned with the direction of wind flow is met maximally by seeing the potential of the wind that ketapak big enough from various directions.

- Many tapering lamiar winds make the potential of a hybrid ventilation strategy for air quality and thermal comforts to occur as can be seen from the flow rate for wind speed and pressure at the site of moderate wind speed category

Separation between male and female occupants is by separating the main facilities ie bedroom, bathroom, and drying room, but shared space is shared, such as assembly hall, dining room, etc. Power of Dormitory, this student dormitory is planned to accommodate $+100-600$ students in 2 HA with the assumption of male student ratio of $60 \%$ of all students who will use the dormitory and female students by $40 \%$. Assuming that this comparison can last for 4 years of their studies. 

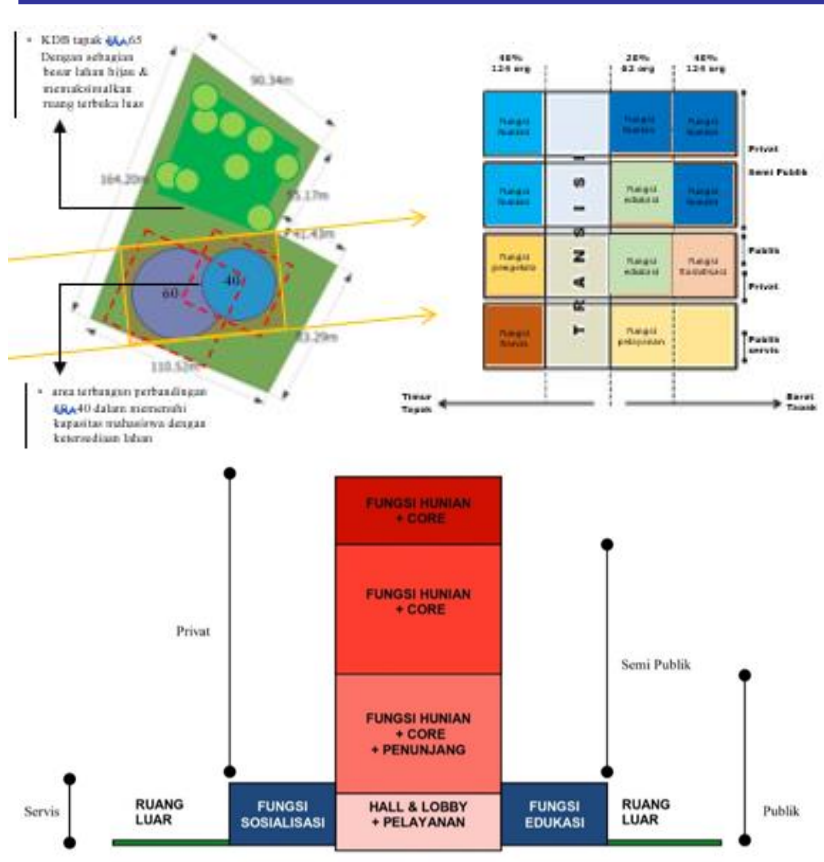

Fig.13 Programatic Dormitory Room

The selected capacity is 1,2 and 3 person per bedroom unit, with advantage:

- Optimum area of sleeping space

- More possible group learning patterns or for discussion.

- Effective as a vehicle for socialization between students.

- Privacy, peace and comfort for the residents is well preserved.

- Different levels of lecture masks are therefore required dormitory rooms with capacity of 1 person and 2 persons in each room.

The shape of the floor plan is the result of the development of incorporation of the recommended forms for bioclimatic buildings. Through its connecting routes used as a reading area of shared reading, other than that the residential area is in the form of a circle arranged following the square axes in the shape of the circle is the point that there is still space to minimize the natural air flow and natural lighting as well as the remaining areas can be used as a sitting area.

The result of breaking atriums with different positions is useful as natural carriage and for spaces that do not require natural exposure and lighting can be minimized with walls supported by practical columns.

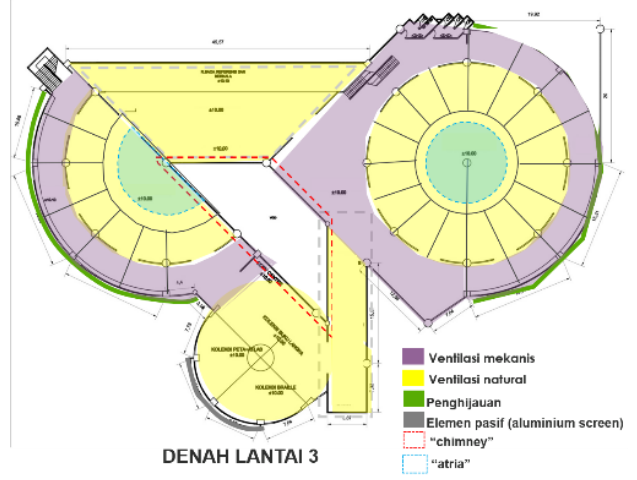

Fig. 14 3rd floor plan of dormitory room

Percentage of area that corresponds to the function of the zone while maintaining balance to the semi-public and public areas in front of the site. the result of the tread analysis embodied with the corresponding quantities between the zoning functions. Among other public and semi public zones that are the zoning that will be highlighted in this building.

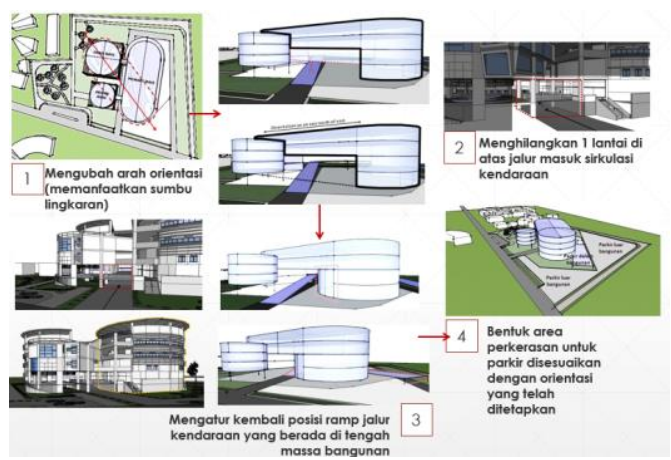

Fig.15 Development of Building Mass

For double leather façad, the insulating glass (thermal barrier) is usually the inner skin, while for the window airflow the insulating glass is the outermost shell. The distance between the two skins usually varies from $0.2 \mathrm{~m}$ to above $2.0 \mathrm{~m}$, depending on the concept and system details. The solar shading device is located inside the cavity between the two skins.

To facilitate natural incorporation and mechanical strength in air distribution systems, the right components may include the Wind Tower, the sun chimney or the atrium for the discharge of the wind. For fan-assissted Ventilation systems are able to adapt to the opening for occupant comfort, comfort tolerance and reduced artificial energy and vital systems are also designed to optimize the use of wind effects due to the plentiful potential of wind flow. 


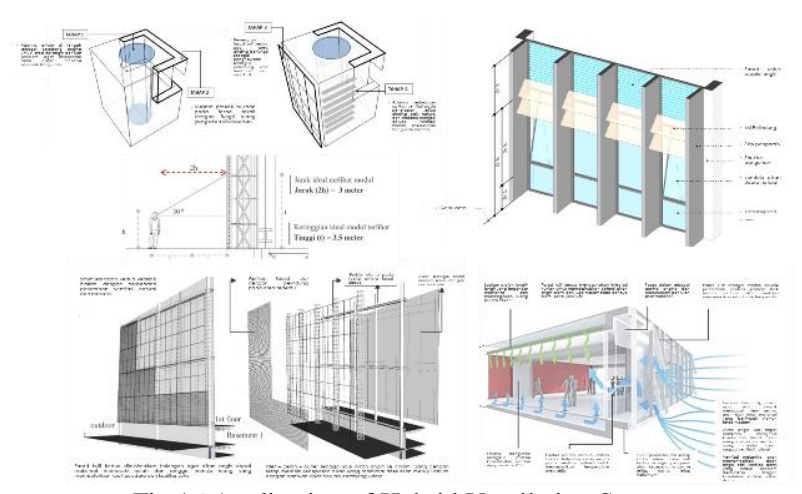

Fig.16 Application of Hybrid Ventilation Strategy

To facilitate thermal comfort control, indoor air quality and airflow within buildings, components such as ventilation or special ventilation of the facade and on the inner wall need to be optimized.

For active design applications and passive designs have been clearly spelled out in specific design criteria in order to achieve success. The likelihood of success has also been explained with success that maximized the minimum medium to high by keeping the following parameters in place.

\section{CONCLUSION}

Designing Dormitory in Lowokwaru by taking the theme of bioklimatik with hybrid ventilation strategy is one of the right building problem solving when applied to the environment tapak villa tidar hill. Student Dormitory Design is strongly influenced by the activities that occur in the building. So that the identification of the background of the subject needs to be done so that the order of the optimal functioning pattern.

With the existence of heterogeneous activity system makes the design exploration becomes more varied.

1. The proposed hybrid venting design is about $30-35 \%$ of the area of the facade or wall of the room function. The hybrid ventilation system can not only save cooling energy, but also improve indoor air quality during midseason when the building is able to passively run to maintain thermal comfort.

2. The combination of fan-assisted Ventilation, based on a natural ventilation system combined with a fan extractor supply makes optimal use of natural driving forces.

3. Preferred room size with shelter function, education and socialization applied width $<6 \mathrm{~m}$ and height $>3 \mathrm{~m}$ will enable a high percentage of success from the application of hybrid ventilation to achieving thermal comfort (temperature quality) and air quality.

4. The combination of glass facades as the second facade for contemporary solutions linked to hybrid vents offers transparency, daylight access and a sense of connection between indoor and outdoor environments, which is superior to that provided by conventional buildings (where windows typically make up about 30 percent of area of the outer wall).

5. In hybrid vents mechanical and natural strengths are combined in a two-mode system in which the mode of operation varies according to the season, and in certain days. Thus the active mode reflects the external environment and takes maximum advantage of the surrounding environmental conditions.

\section{ACKNOWLEDGEMENT}

This article is part of my thesis entitled " Responsive Student Dormitory Design with Hybrid Ventilation Strategy in Education Region of Malang City", under the supervision of Dr.Eng. Ir. Dipl.Ing. Sri Nastiti Nugrahani Ekasiwi, MT. And Dr. Ima Defiana, ST., MT.

\section{REFERENCES}

[1] Prianto, E. (2013). "Green Wall Applications in Government Building in Creating Comfort in Semarang City: A Preliminary Study". Semarang: Riptek Vol. 7 No. I Hal 1-14.

[2] Arie, F. C. (2012). "Surface Temperature Distribution of Land and Its Affecting Factors in Malang City ". Proceedings of National Seminar on Regional Technology Application (ATPW). Surabaya

[3] Gillbuena, R.A \& dkk. (2014). "Design and Development of a Three-Storey Dormitory Building in Muntinlupa City". Manila : School of Civil, Environmental and Geological Engineering (SCEGE)

[4] Liebard, A \& Herde, A. (2012). Bioclimatic Facades. Germany: Observ'ER.

[5] Presidential Decree of the Republic of Indonesia. Number 40 Year 1981. About. Construction of Student Dormitory For Universities All over Indonesia.

[6] Bonny, O \& etc. (2015). "Redesigning Student Dormitory in West Jakarta (Emphasis on Modern Architectural Design)". Jakarta : Imaji Vol.4 No.1.

[7] Chiara, J. \& Hancock, J. (1995). Time Saver Standards for Building Types. 4th edition. Singapore: McGraw-Hill co.

[8] Ji,Y., Lomas, K.J and Cook, M.J., (2009). "Hybrid Ventilation for Low Energy Building Design in South China”. Building and Environtment Journal , 44(11), pp. 2245-2255. Publisher: Elsevier

[9] Heiselberg, P. (2002). Principal of Hybrid Ventilation. Denmark : Komunik Grafiske.

[10] Cross, N. (2008). Engineering Design Methods: Second Edition Strategies for Product Design. New York : John Wiley \& Sons. 